\title{
Carmina de Magister Ludi: o estilo tardio em Max Martins
}

\author{
Carmina de Magister Ludi: the late style in Max Martins*
}

\author{
Abilio PACHECO* \\ Universidade Federal do Pará (UFPA) \\ Universidade Estadual de Campinas (UNICAMP)
}

\begin{abstract}
RESUMO: Neste ensaio apresentamos apontamentos sobre o estilo tardio conforme Adorno e Edward Said e a partir de aí proceder a leitura do poema "X" de Max Martins. Para tanto, propomos estender/distender os significados já operacionalizados para o estilo tardio, de modo a lançar como hipóteses sobre o estilo tardio: sua força de "dínamo" da história literária (avanços e recuos desta), a gênese das obras tardias como resultado da (com)pressão do passado (da tradição) e do futuro (de sua pervivência - das Fortleben), e a relação entre o estilhaçamento formal, a desagregação do ser e a laceração do corpo. A apropriação e a distensão destes sentidos possibilitam um entendimento pouco frequente para a poesia de Max Martins e sugere a interpretação do poema " $\mathrm{X}$ " dentro do contexto sócio político da ditadura militar no Brasil.
\end{abstract}

PALAVRAS-CHAVE: Estilo tardio. Literatura Amazônica. Max Martins. Ditadura militar.

ABSTRACT: In this essay we present notes on the late style according to Adorno e Edward Said and from there proceed to read the poem "X" from Max Martins. Therefore, we propose to extend/distend the meanings already operationalized for late style, in order to launch as assumptions about the late style: its strength "dynamo" of literary's history (advances and backwards of this), the genesis of late works as a result of past's (com)pression (from tradition) and the future (its survival - das Fortleben) and the relationship between the formal splitering, the being's disintegration and the laceration of the body. Appropriation and distention of these meanings enables an uncommon understanding to Max Martins' Poem and suggests the interpretation of the poem " $\mathrm{X}$ " in the socio-political context of the military dictatorship in Brazil.

KEYWORDS: Late style. Amazon literature. Max Martins. Military dictatorship.

Recebido em 21 de outubro de 2016. Aprovado em 8 de dezembro de 2016.

\footnotetext{
* Este texto foi escrito inicialmente para a Disciplina sobre Estilo Tardio, ministrada pelo Professor Pedro Serra da Universidade de Salamanca durante sua estada como professor visitante na Unicamp no $1^{\circ}$ semestre de 2013.

* Doutorando em Teoria e História Literária - IEL - UNICAMP sob orientação do Professor Dr. Márcio Seligmann-Silva e realização de estágio na Freie Universität Berlin nos semestres de Verão/2015 e Inverno/2015-6 sob a orientação da professora Dra. Suzanne Klengel. E-mail para contato: professor@abiliopacheco.com.br.
} 
Max Martins

A tarde era um problema

(emblema)

a

re

(sol)

VER

O parque

Um violino com seu arco - armava a ponte-pênsil

para o crepúsculo

teias

fibra, fi(m)lamentos

entre

sombras, saberes maduros, árvores

em silêncio.

Idem

a Catedral

de granito, dura

enigmagnetíssima

g'ótica

no meio do parque

OLHO

genitoris ego

cêntrico

órgão só ave

$\mathrm{e}$

santo

CANTO

ergo:

Imo

lado: panis

!

D'ego

lado: pênis

Era

a hora do Juízo

Estendido sobre a grama nu o poeta ruminava a sua semente-alvo

Salvo

(e insolúvel) 


\section{I.}

Toda a produção literária ocidental nasce sob o signo do tardio, do estilo tardio. Toda ela traz em si o peso da própria literatura anterior assim como traz em si um elemento aporético bifronte, (am)bícrono que é tanto a semente a partir da qual poderá brotar mais literatura (em textos, estilos e gêneros novos) quanto o germe de sua própria aniquilação, de sua própria destruição; complexamente, a herança da tradição há de conviver com a própria tradição. Mesmo na antiguidade, a literatura escrita carrega/va consigo o peso da literatura oral, mas, ao mesmo tempo em que a substitui em certa medida, com ela convive/eu e mesmo contemporaneamente convive nas emboladas, nos raps, nos repentes, nos cordeis, por exemplo. Por outro lado, exatamente essa protoliteratura escrita que nos legou autores canonizados, estilos e arquitextos, relativamente sistematizados, terminou por estabelecer parâmetros para sua própria aniquilação; parâmetros a partir dos quais, nos primeiros séculos dessa literatura, quaisquer gestos de repetição e imitação terminavam por resultar numa produção de algum modo diverso da "matriz" (mesmo havendo por parte do autor continuador uma intenção de fidelidade), ou parâmetros a partir dos quais, nos séculos mais próximos de nós, os gestos, já não mais de repetição e imitação, mas de dessacralização e destruição/desconstrução, têm se constituído, a partir das ruínas arquicanônico-textuais, dualmente, continuadores e aperfeiçoadores. Tendo em vista a epopeia de Homero (tardia em relação aos cantos orais dos quais o autor grego teria derivado a Ilíada e a Odisséia), tanto é tardia a Eneida, de Virgílio, quanto Ulysses, de James Joyce. Mesmo textos literários absolutamente instituídos como fundadores não escapam desse elemento aporético bifronte e (am)bícrono. Afinal, Dom Quixote (um texto tardio na produção literária de seu autor Miguel de Cervantes) tanto é uma novela de cavalaria $\operatorname{tardia}^{1}$ (e um dos responsáveis pela morte da narrativa ${ }^{2}$ ) quanto é o fundador de gênero literário, hoje, morto: o romance moderno, cujo enterro se dá com James Joyce ${ }^{3}$, em Ulysses, e recebe "a última pá de cal com Finnegans Wake".

\footnotetext{
${ }^{1}$ Nem sempre é fácil apontar os insights, mas este veio-me durante a leitura que fiz este semestre do ensaio A Dulcinéia Encantada de Erich Auerbach sobre o Dom Quixote. In: AUERBACH, Erich. Mimesis. Perspectiva: São Paulo, 1976.

2 "O narrador. Considerações sobre a obra de Nikolai Leskov". In: BENJAMIN, Walter. Obras escolhidas, vol. 1, Magia e técnica, arte e política. Tradução de Sergio Paulo Rouanet. São Paulo: Brasiliense, $1994.7^{\circ}$ edição.

${ }^{3}$ A afirmação de modo peremptório encontrei em Cristóvão Tezza, mas é uma ressonância e uma sintetização de um Zeitgeist teórico. Em $O$ espírito da prosa, ele afirma que o romance teria encerrado
} 
Conforme entendemos, subjacente ao tardio está o dínamo da evolução literária ${ }^{4}$ cujo avanço ocorre de modo não linear, mas constelar, assim como a própria História concebida por Walter Benjamin. As obras tardias, por excelência, à medida que funcionam como mortalhas, que alegorizam a morte, que catatumbam em si mesmas o que são, qual ouroboros, erigem-se fênix a voar sobre as próprias cinzas as quais voltará/ão a ser. A pressão da literatura anterior, a qualidade do cânone estabelecido, o peso da tradição e a sufocante sensação de não haver nada de novo a ser criado (a maldita frase de Mefistóteles ressoa como gritos de Erínias nos ouvidos de cada autor) parecem resultar, especialmente no decorrer do século 20, na angústia de influência ${ }^{5}$, no fantasmagórico agonismo da criação estética e numa atávica sensação de inutilidade do fazer literário; ao mesmo tempo, paradoxalmente, daí decorre a vitalidade pujante do tardio. Seja pelo desejo de imitar os cânones (algo próprio de uma poética que se estende até o Renascimento ou mesmo até o século 17), seja pelo desejo de fundar literaturas (a obsessão Romântica e, em certo sentido, Moderna), seja pelo desejo dessacralizar a literatura (gesto sui generis vanguardista e pós-moderno) sempre está voltada para o clássico. "Os tempos passam e parafraseiam-se"6, como diz Guimarães Rosa. Ou como afirma o mestre Ricardo Reis ${ }^{7}$, "Deve haver, no mais pequeno poema de um poeta, qualquer coisa por onde se note que existiu Homero". A cal ou o sal jogados no passado mais sufocam o presente, e ao passado mais lhes serve de estrume ou rega. Avançasse arrastando consigo a tradição quer seja de mais de vinte séculos, quer seja do século 20. Homero vai revivendo em Virgílio, em Camões, em Fenelon, em James Joyce e tantos outros nas lacunas entre estes e em tantos outros após Ulysses. Da mesma

seu ciclo com "Ulysses, de Joyce, com a última pá de cal de Finnegans Wake". In: TEZZA, Cristóvão. $O$ espírito da prosa. Uma autobiografia literária. Rio de Janeiro: Record, 2012.

${ }^{4}$ Limitamos a citar o gênero narrativo tanto épico como romanesco, mas o mesmo processo ocorre com a tragédia, ou vendo de modo mais amplo com o gênero dramático. De um canto individual ao diálogo (efetivamente sendo falado por duas pessoas) ao que temos hoje, muitas modificações ocorrem sobreescrevendo a tradição. Sófocles ao colocar três personagens no Édipo rei falando em cena deve ter causado espanto assim como Nelson Rodrigues ao dispor um espetáculo em três palcos paralelos em seu Vestido de Noiva.

${ }^{5} \mathrm{O}$ termo é de Harold Bloom. In: A angústia de influência: uma teoria da poesia. Tradução de Marcos Santarrita. Rio de Janeiro: Imago, 1991.

${ }^{6}$ ROSA, João Guimarães. "Desenredo". In: Tutaméia (Terceiras estórias). Rio de Janeiro: José Olympio, 1979.

${ }^{7}$ PESSOA, Fernando: Páginas íntimas e de Auto-Interpretação. Textos estabelecidos e prefaciados por Georg Rudolf Lind e Jacinto do Prado Coelho. Lisboa: Ática, 1996. Pág. 390. 
forma, muita coisa ainda deve sair da mala do pai de Orhan Pamuk, das cadernetas de campo de Guimarães Rosa, da arca deixada por Fernando Pessoa ${ }^{8}$.

Neste artigo, pretendemos desenvolver as reflexões sobre o estilo tardio proposto por Theodor W. Adorno (1937), ampliadas por Edward Said (2009) e desenvolvidas no curso ministrado professor Pedro Serra (Universidade de Salamanca), a partir da leitura de um poema de Max Martins (o poema "X") publicado no livro H'Era, em 1971. Em certa medida, a discussão perpassa pelo problema da Amazônia num contexto de periferia tardia e procura focalizar um ou outro ponto cego acerca do estudo tardio, ou, em restrito, a relação entre as fragmentações formais como vestígios de fragmentação ontológica e da imagem do corpo lacerado como espectro de época (Zeitgeist) da ditadura militar no Brasil.

\section{II.}

No contexto do século 20, a indústria cultural, a guerra de trincheiras, o desenvolvimento urbano, a exploradora economia capitalista e as mais diversas barbáries sociais, além dos adventos técnico-estético da fotografia e do cinema e da força "construdestruidora" das vanguardas artísticas, imprimem ao estilo tardio um processo de reflexão específico e prospectivo. Toda a proposta de entendimento do estilo tardio como dínamo histórico-literário apresentado na primeira sessão desse trabalho corresponde a nossa leitura do ensaio de Adorno, sobre o qual repousam os estudos sobre estilo tardio na obra de Beethoven. Neste pequeno e iluminador ensaio, Adorno inicia como uma bela e rica imagem cuja interpretação por si resultaria em texto seis a dez vezes maior que este, tal seu valor de analogia e sua força alegórica: " $L a$ madurez de las obras tardias de artistas importantes no se parece a la de los frutos (1937, p. 17).

Além do imediato apartamento da arte da esfera biológica e do estabelecimento de uma dialética negativa cotejando explicitamente os aspectos táteis-visuais (não são redondas, mas enrugadas) e palato-gustativas (não são doces, mas amargas) de modo a

\footnotetext{
${ }^{8}$ Orhan Pamuk explica que seu pai costumava ir à Europa para encontrar pessoas ligadas à literatura e guardava informações sobre as viagens na mala que lhe deixou como herança; nela Pamuk sempre encontra novidades. Guimarães Rosa em viagens pelo sertão de Minas Gerais fazia anotações em blocos de papeis que hoje estão na Fundação Casa Rui Barbosa; essas cadernetas alimentam boa parte da pesquisa sobre o autor mineiro. Fernando Pessoa deixou uma arca com os escritos de seus heterônimos e, por opção/decisão sua, a arca só foi aberta 50 anos após sua morte; dela "não param de sair coisas" (SERRA, Pedro - nota de aula, Unicamp, $1^{\circ}$ semestre 2013).
} 
ressaltar a ausência de harmonia clássica, como uma distensão de imagem, podemos compreender que, ao contrário das árvores que, ao atingir sua maturidade produtiva, sempre darão frutos com o mesmo sabor, mesmo havendo cargas de frutos em estágios diferentes (em brotos, de vez, maduros ou pecos ${ }^{9}$ ), os artistas não apresentam em suas obras um estado equilibrado dos seus primeiros aos seus últimos trabalhos. As obras apresentam certo prosseguimento evolutivo raramente linear, pois o trabalho intelectual está fatalmente fadado a erros e insucessos, a saltos e recuos, especialmente se considerarmos poetas com alta preocupação teórico-prática e alto investimento intelectual. Ao contrário do fruto que nada deve ou teme em relação aos frutos anteriores, nem tem consciência da existência futura de outros frutos, na obra de arte é possível depreender um gesto criador agônico compelido tanto pelo peso do clássico, do cânone, da tradição quanto pela própria obra anterior do artista, também podemos depreender neste gesto certo constrangimento pela perspectiva da solapação desta obra pelas que virão ${ }^{10}$. Se chegamos "tarde e a poesia é velha", como afirma Ruy Belo (apud SERRA, 2013, p. 13), qual a finalidade de se escrever mais poemas sem cair em banalização ${ }^{11}$ que aponta tanto para uma mera inscrição numa indústria cultural, que se procura negar, quanto para risco da não pervivência (Fortleben) das obras ${ }^{12}$ ? Se "ser moderno é ser tardio"13, como afirma Edward Said em Temporalidades fora da História, e o estilo tardio da modernidade tardia do século 20 muda a relação das obras com a tradição, com o clássico, ao mesmo tempo em que se negam mas fatalmente podem se erigir como tal, as obras dos artistas dos últimos sessenta ou setenta anos,

\footnotetext{
${ }^{9}$ Embora a expressão sempre me soasse regional norte-nordestina, ela está dicionarizada: "doença dos vegetais que os faz definhar" (Houaiss). São frutas que não amadurecem e, em geral, ficam com um gosto salobro.

${ }^{10}$ Aqui eu ouso acrescentar uma hipótese que me acompanhou durante boa parte do curso, mas que ganhou a devida dimensão na aula sobre Herberto Helder, no dia em estava sendo lançado em Portugal seu mais recente livro de poemas. Se não é a imediatez da morte que incita no poeta à criação tardia, $o$ que fazermos com poetas vivos cujas obras tardias estudadas não são as últimas? O que fazer com um inédito recém-lançado de um autor que na obra anterior já é tardio? Tento resolver o problema de algumas formas: fazendo certa relativização do tardio e procurando mostrar que o estilo, não sendo compelido pela morte, é resultado da pressão tanto da tradição quanto da pervivência.

${ }^{11}$ Essa pergunta é uma paráfrase do que ouvi de Milton Hatoum na X Feira Pan-amazônica do Livro, em Belém [19 de setembro de 2006]: "Existem muitos romances, então para que escrever mais um?" (reproduzo de memória). No mesmo ano, ouvi Caetano Veloso, em entrevistas de lançamento do seu novo CD, "Cê", afirmar algo semelhante: "Penso muito nesta ideia: com tantas canções que existem neste mundo, qualquer um se deveria perguntar porquê fazer mais uma canção?" - www.expresso.sapo.pt

${ }^{12} \mathrm{O}$ termo é extraído do ensaio "A tarefa do tradutor". In: BENJAMIN, Walter. Escritos sobre mito $e$ linguagem (1915-1921). Organização e apresentação de Jeanne Marie Gagnebin. Tradução de Susana Kampff e Ernani Chaves. São Paulo: Duas Cidades/ Editora 34, 2011.

${ }^{13}$ Anotação de aula.
} 
sobretudo em países europeus periféricos como Portugal e Espanha ${ }^{14}$, some-se a isto o contexto das ditaduras, já desde as primeiras publicações, aborrecem o equilíbrio e a harmonia clássicos e agonizam expondo-se o suplício do criador e os andaimes da construção $^{15}$ (para nos vincularmos apenas aos dois pontos apresentados por Adorno nas primeiras linhas do ensaio). Nas obras desses poetas, que desde os primeiros livros já se apresentam sob o signo do tardio no século 20, deve haver algo de significativamente importante que a nossa mentalidade ainda não procurou discernir.

Dizer que esses poetas escreveram sob a coação da morte, não é nada novo. A literatura desde Sherazade guarda pontos de contato com a temática da morte. Narrar para não se deixar morrer e narrar para não deixar que se morra - Sherazade não estava errada; além de salvar-se a si, ainda salvaria a irmã. Se nos tempos das Mil e uma noites as obras tinham o dever de conferir imortalidade, com o tempo passaram "a ter o direito de matar" e a imagem do autor tende a seu desaparecimento (FOUCAULT, 2000, p. 45). Entretanto, Adorno critica a leitura da obra tardia vinculada à expectativa da morte do sujeito (1937, p. 19). Na modernidade, cada vez mais nos afastamos da visão da morte, sua força evocativa definhou, sua capacidade de gerar conhecimento ou sabedoria perdeu-se (BENJAMIN, 1994, p. 205). Tentar ver em todo autor tardio a lâmina do algoz de um sultão ou a foice da "indesejada das gentes" (como a chama Manuel Bandeira) determinando os sentidos, os estilos e as características de sua obra, é não compreender as diferenças entre a dimensão estética e a dimensão biológica. "Poemas não nascem nos galhos das árvores" (nota de aula - 04.03.13), são constructos atualizáveis. "Tem sangue eterno e asa ritmada", enquanto ao poeta deve restar a consciência de que um dia estará mudo (do poema "Motivo", de Cecília Meireles). A morte, a proximidade da própria morte, não é decisiva para o estilo tardio. Ela "está impuesta unicamente a las criaturas, no a las obras, y por eso siempre aparece encubierta em toda arte: como alegoria" (ADORNO, 1937, p. 17).

Ser tardio no século 20 é ser um tradutor de catástrofes, é ser um cosedor de mortalhas, um artesão de alegorias, um burilador de ruínas. O estilo tardio entendido

\footnotetext{
${ }^{14}$ A condição periférica desses países, ou simplesmente o uso desses termos, pode suscitar ou demandar algum debate, mas entendemos que textualmente estão compreensíves e bastam em si.

${ }^{15}$ Aqui refiro ao soneto do poeta parnasiano brasileiro Olavo Bilac, "Longe do estéril turbilhão da rua...", no penúltimo terceto afirma: "Não se mostre na fábrica o suplício / Do mestre. E natural, o efeito agrade / Sem lembrar os andaimes do edifício". A presunção ainda clássica de conferir à obra uma ilusão de realidade é associada à obra como objeto pronto acabado, "redondo".
} 
como "arte que sobrevém depois da catástrofe" (SERRA, 2013, p. 09) trabalha o resíduo, o fragmento, a dissolução. A obra tardia ao encobrir a morte com a alegoria efetua um gesto tradutório. Todo o século 20 recende a morte, a mortos; eis a inspiração da poesia tardia; eis sua musa. Respirou-se, respira-se ainda este ar. A História não acabou, não chegamos ao fim da História ${ }^{16}$. Não há páginas a serem viradas, há páginas a serem reviradas, e reviradas tantas vezes preciso for. Precisamos desenterrar nossos mortos, baldiados em valas comuns, para enterrá-los com velo e rito. O verbo tardio exercita o luto, guarda-o; criam-se túmulos no $\operatorname{ar}^{17}$. O 'gesto colérico' do artista tardio pretende erigir na linguagem um topos destrutivo onde este ar não desapareça e a mortalha que encobre a morte menos pareça um manto real que um molambo. No entorno dos poetas de países dominados por ditaduras (ou outros sistemas autoritários/totalitários), há o reflexo, não da iminência da morte dos próprios poetas, mas das iminências das mortes havidas, não enlutadas e não esquecidas, e outra vez como que havidas, diuturnamente havidas. Não bastasse a morte, o verso/verbo destroça-se, dilacera-se, torna-se irreconhecível como tal, refratada imagem do corpo macerado pela tortura. No verso/verbo estilhaçado, vemos o ser destituído de sua dignidade de sujeito ${ }^{18}$. Isto lemos também a partir de Adorno. Para ele, a subjetividade, nas obras de arte tardias, não está para expressar-se, mas para explodir. Suas convenções se estilhaçam, fragmentam-se. As obras são atravessadas mais por ausências e resíduos, 'escombros' e 'fissuras'. Para outra vez serem expressão: “no ya del 'yo' individual, sino de la índole mítica de la criatura y su caída" (1937, pp. 17-8). E, ao se expressarem como representação de si mesmas, tendo toda pletora de recursos de linguagem, as obras tardias bastam-se em si. Apresentam-se como "conflagración entre los extremos", onde a força da subjetividade surge no desarmônico, na palavra seccionada, no verso anômalo ou não-verso, no ritmo dissoluto ${ }^{19}$, imprevisto, de carro de boi em estrada esburacada ${ }^{20}$, na estrofe precária, desarquiteturada. Entretanto, nessa

\footnotetext{
${ }^{16}$ É uma frase-mito-título. FUKUYAMA, Francis. "The end of history?". In: The National Interest, Summer, 1989. The End of History and The Last Man. New York: The Free Press, 1992.

${ }^{17}$ Referência ao verso de Paul Celan: "cavamos um túmulo no ar onde não se há de estar apertado" ("wir schaufeln ein Grab in den Lüften da liegt man nicht eng", do poema "Fuga da morte" ("Todesfuge"), do livro Ópio e Memória (Mohn und Gedächtnis), 1952.

${ }^{18}$ A tortura, além de retirar do indivíduo sua dignidade humana, tem como objetivo "provocar a explosão das estruturas arcaicas constitutivas do sujeito, isto é, destruir a articulação primária entre o corpo e a linguagem” VIÑAR, Maren \& VIÑAR, Marcelo. Exílio e tortura. São Paulo: Escuta, 1992. p. 73.

19 Título do terceiro livro de poemas de Manuel Bandeira, publicado em 1924.

${ }^{20}$ A imagem é de João Cabral de Melo Neto.
} 
imagem do poema que causa estranhamento, imagem da página como um chapisco de palavras, resulta uma figura compreensível em sua unidade.

\section{III.}

Max Martins não é um poeta popular no sentido que este termo é comumente empregado, mas é um poeta bastante conhecido tanto no meio universitário (professores e alunos dos cursos de Letras) quanto entre os poetas paraenses residentes no Pará, sobretudo em Belém e proximidades. Pode-se dizer que é sempre lido nestas duas esferas, o que nem sempre resulta num poeta bastante entendido. Falecido em 2009, dentro do cânone regional, Max apenas se vincula com outros dois poetas: Mário Faustino (1930-1962) - nascido no Piauí, mas radicado no Pará -, que lhe é anterior, e Age de Carvalho (1958-).

Os três primeiros livros de Max Martins, O estranho (1952), Anti-retrato (1960) e H'era (1971) revelam, segundo Bendito Nunes (1991), as bases dos três primeiros momentos da sua produção ao mesmo tempo em que o terceiro encerra um ciclo e firmará "a fisionomia espacial da sua obra" (1991, p. 29). É preciso ressaltar a condição tardia da Amazônia, em especial de Belém do Pará, no contexto das letras e da cultura brasileira da época. A condição tardia na Amazônia ${ }^{21}$ encontra sua melhor síntese na afirmação feita pelo poeta ludovicense Ferreira Gullar ao dizer que nasceu e durante muitos anos viveu em Macondo ${ }^{22}$. Ferreira Gullar ainda era parnasiano até que se deparou com o primeiro Drummond escrevendo "com letras de macarrão" 23 e, de imediato, rejeitou aquilo que para ele não era poesia. Também os poetas da década de 40, em Belém, estavam rimando e metrificando seguindo o Tratado de versificação, de Guimarães Passos. Mesmo a passagem de Mário de Andrade pela capital paraense em 1927 não surtiu algum efeito nas letras paraenses (os contatos com o poeta paulista preocupavam-se mais com os estudos sobre folclore) (NUNES, 1991, p. 19). Belém insulava-se e a Amazônia isolava-se. A queda da economia da borracha, fim dos

\footnotetext{
${ }^{21}$ As questões teórico-geográfico-culturais sobre a aceitação de São Luís como parte da Amazônia Brasileira ficarão aqui ausentes. Sem nenhuma implicação a mais, as condições de atraso cultural de São Luis da sua época não se diferem muito das condições de Belém de Max Martins e isso é o que nos importa neste momento.

${ }^{22}$ Foi na VII Feira PanAmazônica do livro, em 2004, que ouvi Ferreira Gullar comparar a capital maranhense à cidade criada por Gabriel Garcia Marquez, em Cem anos de solidão. As frases seguintes são citações de memória da entrevista concedida por ele durante a feira.

${ }^{23}$ Poema "Sentimental", em Alguma poesia, 1930.
} 
áureos tempos de riqueza (que haviam colocado Belém nas primeiras décadas como uma das cinco principais capitais brasileiras) e as restrições de voo sobre a Amazônia durante a Segunda Guerra Mundial podem não ser determinantes, mas figuram-se como agravantes para a condição tardia da poesia na capital paraense, onde vão desaguar a fase heroica do modernismo a cavaleiro de sua crítica, juntamente com a sobriedade de 30 e a turbulência da geração de 45 .

Embora possam se encontrar raros rasgos parnasianos em $O$ estranho, a poesia forjada ao gosto clássico faz parte da pré-história do poeta e está toda ela nas páginas dos suplementos literários em que ele e os demais autores de sua geração publicavam; quiçá, nesta produção, como no único soneto publicado em seu primeiro livro, já despontassem traços/sementes desse Max da década de 1970 em diante ${ }^{24}$. Benedito Nunes, que fez parte da mesma geração de Max e lia a produção do amigo no calor da hora, apresenta um rol de autores determinantes para formação intelectual de sua geração na década de 40 e afirma assistir o nascimento de uma "atitude racional do poeta como artista da palavra, ciente da forma de elaboração de seu poema sob o controle da inteligência, um pouco mais tarde singularizada na poética de João Cabral de Melo Neto" (1991, p. 22). Apesar disso e apesar de $O$ estranho ter sido lançado um ano depois de Claro enigma (1951), de Carlos Drummond de Andrade, Benedito Nunes afirma que constatou, à época do lançamento, o fato da vinculação da poesia de Max em seu livro de estreia ser mais com o Drummond de Alguma poesia (1930), Brejo das almas (1934) e José (1942) e condenava, em ambos, a fragmentação como elemento composicional. $O$ estranho, cujo título já aponta para um poeta que surge tardio, exilado na palavra, cujo poema-título começa indiciando este degredo verbal ("não entenderás o meu dialeto / nem compreenderás os meus costumes”, Max Martins, 2001, p. 347), apresenta, se levarmos em conta a crítica inicial de Benedito Nunes, um duplo gesto tardio avant la lettre.

A partir de uma leitura global da obra de Max, no prefácio escrito para os Poemas reunidos (1991), Benedito Nunes revisa a crítica feita no calor da hora e reconhece que a fragmentação, terminava por prenunciar uma das marcas da poética de Max Martins. Segundo ele, "a convivência intelectual com Robert Stock e o impacto de Mário Faustino, O homem e sua hora (NUNES, 1991, p. 25) foram decisivos para Max

\footnotetext{
${ }^{24}$ Talvez eu pareça conversar com um auditório específico. É verdade. A poesia confinada nos jornais lá permanece. Falta pesquisa.
} 
Martins melhor compreender a linguagem como "criadora de objetividades novas", por na ordem do fazer poético o rigor do trabalho formal e avançar na assimilação do uso do espaço da página, num gesto vanguardista concretista, do qual Mário Faustino foi mediador naquela época em Belém” (Benedito Nunes, passim).

Sobre o segundo livro de Max Martins, basta-nos a afirmação de Benedito Nunes:

Anti-Retrato avançaria timidamente nesse domínio. Mas foi nesse livro que a temática do amor carnal começou a tornar-se o centro da obra de Max, desde então ligada à ideia de poesia enquanto arte exigente e ao mesmo tempo exercício de vida. A incorporação do espaço como distribuidor de ritmo e revelador visual do significado, o poema passando à categoria de composição topográfica inclusiva de um desenho letrista, icônico, adviria na terceira crise, encetada em H'era (1971) e resolvida em $O$ ovo filosófico (1975), que precedeu $O$ risco subscrito (1976), culminância desse período. (1991, p. 27).

A descontinuidade evolutiva aos sobressaltos, mas com certas constantes, conforme afirma Nunes, tem em H'era (1971), todo o peso bifrontal, atarrachador, da poesia tardia como a vimos concebendo. Ao lado dos primeiros poemas que neste livro melhor evidenciam aquilo que Nunes chama/ou de "fisionomia espacial característica" (1991, p. 29), passeiam poemas ao sabor das redondilhas rimadas e metrificadas. Embora H'era, como obra tardia, padeça à/a pressão da obra anterior, interessa-nos aqui o quanto há de gesto prospectivo. Não sendo a obra mais recente do autor, as pegadas deixadas nesta poética terminam não sendo lidas em si, mas da frente para traz. Isso só é possível, pelo fato de nestes poemas haver qualquer coisa de gesto vanguardista, mesmo 40 anos depois, não amoldado no senso geral da poesia atual, uma lírica ainda estranhada, feito fruta avinhada ao gosto do leitor. Em seu lirismo bandeirante, de detrito de palavras chapiscadas e de versos esgarçados, vítimas de uma violência organizada da linguagem, que melhor vai se realizar, praticamente achando seu modus operandi definitivo em $O$ risco subscrito (1976), reside uma poética de "carnalidade do mundo", de "atração fálica do corpo feminino", de obsessiva recorrência masturbatória de triunfo fálico, de escavação da linguagem e de recuperação do ser "no gozo da 
escrita" (NUNES, 1991, passim). Como podemos ler no poema "Koan"25, que juntamente com "X", são os únicos poemas neste livro (H'era), em cuja espacialização ocorre em versos centralizados.

Cavo esta terra - busco num fosso

$$
\begin{gathered}
\text { FODO-A! } \\
\text { agudo osso } \\
\text { oco } \\
\text { flauta de barro } \\
\text { sôo? }
\end{gathered}
$$

Além da centralização, a fisionomia lírica fragmentária ordenada se apresenta neste livro como ensaio daquilo que Benedito Nunes vai chamar de "desenvoltura lúdica" assinalada pelo "espacejamento rítmico, ou seja, a distribuição espacial das palavras segundo um ritmo semântico, a pausa realçando a significação" e por uma "pletora de recursos formais" (1991, p. 43). H'era já antecipa, especialmente em "Koan" e "X", mas também na série de quatro poemas intitulado "Travessia" (uma clara referência tributária a Guimarães Rosa e seu Grande sertão: veredas), a poesia como resultado de um empenho intelectual, de um trabalho técnico e de uma alta consciência no emprego dos recursos expressivos da linguagem.

\section{IV.}

Max Martins é um poeta muito cioso também nas escolhas dos títulos. Neste seu livro, tal cuidado traz certo gesto de artífice desde o título: H'era, que é também o título do primeiro poema. Contígua e cumulativamente neste título lemos as duas palavras que se deslindam nos dois versos iniciais:

Em verdes eras - fomos

hera num muro

O título do poema que selecionamos para com ele iluminarmos algum ponto cego do estilo tardio, a princípio não nos deixa dúvida. " $\mathrm{X}$ " não é o décimo poema, ou seja, não é um numeral romano, mas sim a letra "X" que em matemática corresponde à incógnita de uma equação, ou a qualquer outra variável desconhecida, em trigonometria

\footnotetext{
${ }^{25}$ Em nota de rodapé, Max explica que "Koan" é formado por dois demonstrativos oriundos do Tupi e significam "aquilo que está longe, invisível".
} 
ou em álgebra, ou numa expressão matemática escrita a partir de um problema ${ }^{26}$. Curiosamente, a letra grega "quia" foi determinada para significar "algo", devido a uma questão fonética. Quando os pensadores medievais espanhóis beberam do conhecimento matemático oriental, a palavra árabe usada nos problemas representava um som ausente em espanhol: "sh". O poema nos propõe um problema, ou se propõe como problema, como um desafio à leitura. $\mathrm{O}$ espectro do poema na página já configura à/a primeira vista 'arrugado', 'áspero' ao paladar domesticado à relativa harmonia estética. Os versos também não deixam por menos, resistem à leitura declamatória e à memorização. Não existe enquanto massa sonora desacoplada de sua conformação visual. O poema é coisa, produto de humana mão, que demanda sua existência material.

À leitura dos primeiros versos somos instigados à tarde poemática, problemática, onde um eu-lírico afastado, obtuso e obstruso, rebela-se à segurança clássico-romântica de uma primeira pessoa verbal. Ao leitor resta caminhar conduzido por este guia ausente, mas fantasmaticamente presente. A tarde, emblema, insígnia desta poética, paisagem fraturada, estilhaçada pela/na frase deslinearizada, no corpo-palavra suturado/a em decomposição não-morfossintática do verbo no infinitivo "resolver". O gesto agônico nesta poética (que busca, nas palavras, respostas), não tem a precisão cirúrgica do Linguista que retalha a palavra em morfemas. O poeta aborrece a lógica, $\mathrm{o}$ racional, o gesto cartesiano-iluminista. Cinde a palavra onde lhe der na telha, onde for conveniente, onde a palavra se deixar e se desejar rasgar, e o faz com fios dados a si, opera com instrumentos dispostos à própria linguagem: hifens, parênteses, maiúsculas, apóstrofes, barras, dois pontos... Neste início de poema, o gesto artesão de Max Martins sobre a palavra "resolver" abre pelo menos duas visadas, as quais podem desaguar em mesma foz. Cada sílaba do verbo "resolver" é disposta numa linha diversa, encerrando em si um sentido coadunante e destacando as duas últimas sílabas como palavras, uma entre parênteses '(sol)' e a outra em caixa alta 'VER'. Ou: há uma incisão do (sol) no verbo "rever" - re(sol)VER. Sendo (sol) relacionado à ideia expressa em 'tarde' e 'VER' à '(emblema)'. Num ou noutro caso, o gesto criador atua vigorosamente na conflagração de uma imagem debuxada, bosquejada, ao mesmo tempo em que insinua, na incógnita, a via sensível do olhar como modus operandi à busca ensejada no poema. Faz parte desse jogo de insinuação "o parque", objeto de olhar e de estar(se), e que

26 " $\mathrm{X}$ " também não é queijo, como nos cardápios de lanchonete, em que a letra é usada para indicar a presença de queijo num hambúrguer ou sanduíche, devido a parofonia entre xis e cheese. 
carrega consigo o sentido mesmo do lúdico. Nesta poética como a estamos descortinando, o ledor deve, necessariamente, ser um vedor.

Nesta primazia do significante, equipara-se o aspecto $^{27}$ sonoro ao visual. Os jogos eufônicos, as sugestões sonoras ou os jogos intersemióticos no corpo do poema co-operaram para a erição do poema, objeto criado para contemplação visual e contentamento auditivo, mas que não se domesticaliza à exposição declamatória, recitativa e passiva dos saraus. "X", mais que criar sugestões sonoras, faz eclodirem memórias auditivas. O poema resiste ao que possa obturá-lo de sua materialidade onde este realiza sua desenvoltura lúdica verbivocovisual. Palavras, sons e imagens, onde persiste a tarde, agora, crepusculante e silente. Do violino, o arco em suspenso, somado aos 'sabres maduros', diante da carregada melancolia do ocaso e da proximidade solene da catedral de onde provém o Ângelus, revela um incitante toque de erotização associado a uma tônica negativa carregada de pulsão de morte as quais, ao lado do labor técnico-narcísico da linguagem, agravam a busca pelo "X", por "algo", ao mesmo tempo em que tornam mais imponente a imagem (emblema) da tarde. Enquanto a primeira estrofe erige-se numa estrutura precária sendo "esqueleto gráfico" (NUNES, 1991, p. 37), aqui a conformação espacial se apresenta mais distensa, aparentemente menos precária e fragmentária, mas com jogos eufônicos (a assonância em "s") e um achado de linguagem que enceta o gesto tardio do autor e se inscreve naquela dimensão bifronte que ora vimos indicando. A incisão feita em 'filamentos' (palavra que harmoniza com 'fibras' e 'teias' que lhe são anteriores) de uma letra 'eme' entre parênteses resultando em "fi(m)lamentos" lança a palavra de encontro ao "crepúsculo" (fim) e antecipa a "catedral" (lamentos).

Da estrofe seguinte, deveríamos falar apenas de sua organização espacial ovoide. O ovo e o olho ainda se tornariam a obsessão do poeta (leia-se, por exemplo, a sequência de poemas intitulada "O ovo filosófico", publicado em $O$ risco subscrito (1976), e aqui vemos um poeta em treino, experimentando recursos já da maneira ousada como depois se verá de modo mais constante e mais refinado. Como dissemos, é um poema que exige ser visto. O formato da estrofe (o sol se pondo ${ }^{28}$ ), repousa em

\footnotetext{
27 Talvez não seja a melhor solução, mas não me agrada a ideia de estratos, camadas, que se sobrepõe. Tanto pretendo escapar da tendência hierarquizadora que a palavra 'camada' apresenta quanto pretendo preservar a ideia de concomitância que a ideia de camada rejeita.

${ }^{28}$ Pouca gente se atreve a dar uma leitura interpretativa a Max Martins. Talvez nem seja para tanto e o que faço aqui em nada contribua (o poema é o poema é poema...), mas as interpretações que tenho
} 
"ótica" e "olho" explícitos no texto. Esses nove versos são semanticamente muito ricos e bastante sobredeterminados. Neles ecoa o som que vem da Catedral ${ }^{29}$ e mesmo o "Idem" inicial, que estabelece uma relação de contiguidade com a estrofe anterior, aqui vai soar como uma paródia (quase literalmente canto-paralelo) ao "amém" cantado na igreja. Podemos notar um jogo lúdico, apenas esboçado (não sendo epopeia nem tragédia, o poema exige certa compressão nas formas), com o "Tantum ergo", um canto católico composto por São Tomás de Aquino, e entoado durante as bênçãos do Santíssimo. Nos dois últimos versos, a força intertextual se soma ao labor formal de MM ao justapor as leituras de "genitoris ego" e "ego / cêntrico". O "pai" do hino sacro entrelaçando-se ao desejo do eu-lírico. A busca do poeta pelo " $\mathrm{x}$ " perdura. O parque torna a aparecer como espaço lúdico profano (literalmente, fora do templo) por onde o poeta tangencia-se da catedral. O enigma, da catedral "enigmagnetíssima", participa em boa parte do jogo verbal da busca deflagrada desde o título.

O som do órgão que atravessa o fim de tarde, a sugestão erótica contida em ‘órgão' e 'ave' e a propagação do "santo / CANTO”, não conduzem o poeta a conclusão alguma. "Ergo" cumula a decisão solitária do poeta (verbo erguer) e a suposta conclusão (conjunção latina 'portanto'); suposta, posto ensejar mais dúvida, ou ensejar 'a' dúvida. $\mathrm{Na}$ oposição entre o sacrifício religioso contido em "imo / lado: panis" e o prazer solitário em "d'ego / lado: pênis" ${ }^{30}$, textualmente comparece na mesma linha do par parônimo "panis/pênis", centralizado e logo abaixo de "ergo", um ponto exclamação o qual, longe de indiciar qualquer certeza, mais parece-nos apontar para algo que até o momento falta nesta busca: a pergunta. Nesses pares de versos, repousam um trabalho de carpintaria verbal de poeta cioso e hábil no trato com a palavra não só de seu idioma, mas também das potencialidades criadoras no trato com outros idiomas, neste caso, com o latim.

Para agravar mais ainda o peso do desejo logo manifesto em ato, a hora do angelus passa a 'Era'. O poeta teme e não parece temer o que na Igreja Católica se convencionou chamar "a hora do Juízo" (algumas denominações cristãs não católicas

escutado pouco me convencem. Já ouvi algumas explicações diversas para este formato de poema: seria um olho observando a catedral, seria um ovo da ave sozinha ('só ave'), seria a imagem de frontispício de uma catedral e, por fim, a mais risível, seria um clitoris (?), as estrofes acima seriam os pelos e a estrofe seguinte a vagina aberta, lado a lado os grandes lábios.

${ }^{29}$ Quem sabe alguém ainda veja no formato ovoide da estrofe, a hóstia do sacramento.

${ }^{30}$ Embora não dicionarizado, pelo menos não no Houaiss que uso, degolar na região é um termo (chulo?) para masturbação. 
chamam de 'o dia do Senhor'). Uma referência ao sétimo versículo do capítulo 14 do Apocalipse $^{31}$. O poema encerra com o gozo solitário do poeta (se masturbando) na grama do parque. Livre das pressões impostas ("salvo"), porém ainda com seu ' $\mathrm{x}$ ' insolúvel.

V.

Para além desse violento ato de leitura do poema e das questões religiosas implicadas à sexualidade, importa-nos o trabalho poético contido no gesto temporão de Max Martins e a tentativa de clarificar algum ponto cego do estilo tardio, em restrito, a relação entre a 'fisionomia espacial' como registro espectral do ser desintegrado e com imagem irreconhecível do corpo.

Como dissemos, "X" é um poema no conjunto da obra de MM que põe em relevo o significante (em seu aspecto visual) através - dentre outras coisas - do uso de parênteses, apóstrofes, parônimos, pares opositivos, das incisões verbais que possibilitam jogos de sentido, além do emprego de consórcios e divórcios das palavras formando encadeamentos inusitados de sentidos e da instalação de duplas possibilidades de leituras. Recursos que ao/por causarem estranheza e oferecerem certa resistência à leitura, problematizam junto com o leitor questões importantes sobre o fazer poético, demandam (também do leitor) um alto grau de investimento/empenho estético e são, em primeiro lugar, linguagem. A poesia tardia já não mais põe encena a mímesis da ação da poesia clássica, nem a mímesis da emoção da poesia romântica. Aqui o objeto da poética é, em primeiro lugar ou unicamente, linguagem. Max Martins neste poema de H'era põe em cena exatamente isso que será cada vez mais sua busca até culminar em $O$ risco subscrito (1976). A maioria dos poemas deste seu terceiro livro trabalha o que representa o resultado da última crise de Max Martins com o fazer poético (NUNES, 1991, p. 27), sobretudo os poemas "Koan", "Travessia" e o aqui esquartejado e quase dissecado "X", além de funcionarem como um reservatório bifronte, (am)bícrono, são seus primeiros exercícios de exílio na palavra.

\footnotetext{
31 "Dizendo com grande voz: Temei a Deus, e dai-lhe glória; porque é vinda a hora do seu juízo. E adorai aquele que fez o céu, e a terra, e o mar, e as fontes das águas”.
} 
H'era é também o primeiro livro de Max publicado durante a Ditadura (Civil-) Militar no Brasil ${ }^{32}$, e faz parte juntamente com $O$ ovo filosófico (1975) e $O$ risco subscrito (1976), do período relacionado às respostas para a sua terceira crise poética. H'era é bifronte também neste sentido, do mesmo modo que avança no trabalho poético levando trás si redondilhas, é um livro que ainda guarda em seus poemas indícios de uma referencialidade externa ao fazer poético. Nele podemos encontrar, por exemplo, poemas que lembram a poesia práxis (ao gosto de Mário Chamie): "o não da fome / apaga o homem" (p. 310) e o seu mais conhecido, declamado, musicalizado e estudado poema Ver-o-peso (p. 307). Ver-o-peso é o único poema segundo Benedito Nunes onde é possível detectar certa fisionomia e certa fisiognomia de Belém ${ }^{33}$. O caminho para este exílio na linguagem poderia ser considerado como encerrado quando em 1980, o próprio poeta se refugia em Marahu, "numa existência individual solitária e autônoma, longe e perto da cidade" (NUNES, 1991, pp. 27-8) e, dessa experiência, temos Caminho de Marahu (1983) е Marahu poemas (1991).

O estranhamento causado pela ausência da participação social de certos intelectuais, especialmente escritores de significativa penetração social e bastante cônscios de seu papel na sociedade, e o estranhamento causado por uma linguagem onde o sujeito lírico parece um autômato alheio ao cenário social e que parece sequer estar "jogando milho aos pombos" 34 , encontram guarida na ideia exílio na linguagem, como algo próprio do estilo tardio como este se apresenta no século 20. Este exílio se constitui, segundo Edward Said, num "momento em que um artista em pleno controle de seu meio estético abandona a comunicação com a ordem social estabelecida de que ele é parte para chegar a uma relação contraditória e alienada com ela” (2009, p. 28).

A publicação de H'era ocorre num dos períodos de maior violência política no Brasil. Sob o cetro de Emilio Garrastazu Médici, as práticas de tortura já existentes, se tornaram cada vez mais frequentes, sistemáticas e integradas à rotina tecnocrata como

\footnotetext{
${ }^{32}$ Compartilhando as reflexões de Carlos Fico, para que, "se a preparação do golpe foi de fato 'civilmilitar', no golpe, propriamente, sobressaiu o papel dos militares" (Fico, 2004: 52).

${ }^{33} \mathrm{Na}$ série Memórias literárias, ocorrida durante a X Feira Panamazônica do Livro, em 17 de setembro de 2006, professor Benedito Nunes proferiu a palestra: "A Belém de Max Martins". Sua frase inicial foi "deram-me um tema que não existe".

34 Verso da canção Milho aos pombos, de Zé Geraldo. O verso virou expressão popular para inércia política na década de 1970, muitas vezes ouvi como provérbio sem saber que fazia parte da canção, que começa com os seguintes versos: "Enquanto esses comandantes loucos ficam por aí / Queimando pestanas organizando suas batalhas / Os guerrilheiros nas alcovas preparando na surdina suas / Mortalhas // A cada conflito mais escombros / Isso tudo acontecendo e eu aqui na praça / Dando milho aos pombos".
} 
um expediente banal. O cenário em Belém e na Amazônia não era diferente e a classe artística não esteve imune. Assim como em todo Brasil, as perseguições políticas resultavam em prisões, tortura, morte/desaparecimento ou exílio. A intelectualidade, especialmente universitária e de esquerda, deparou-se com o assombro do golpe tanto por sua dimensão (considerando o tamanho do Brasil), quanto por sua rapidez (mesmo na Amazônia onde tudo demora a chegar, houve prisões antes mesmo da noite de 31 de março de 64), e teve que conviver com as notícias de companheiros que caíam e com o medo de também cair ${ }^{35}$. Pior que o medo da morte/desaparecimento, era o medo da tortura. E o único escape, nem por isso isento de alguma dor, era o exílio. Entendemos que o exílio na linguagem de alguma forma vincula-se a um gesto de exílio político e refúgio da morte e da tortura, resultando num texto como mortalha, como objeto violentado. Em autores que viveram sob o espectro das ditaduras militares em seus países, o estilo tardio parece enlutar na sua fragmentação formal a fragmentação do ser, a destruição do verso, os cortes aparentemente arbitrários morfossintáticos ou não, o espargimento dos resíduos verbais pela página, a aparente desarticulação do todo... suscita a pergunta: Se questa è una poesia $?^{36}$ Desubjetivado?, o rigoroso gesto poético de perícia, de técnica, destrutiva num gozo de pulsão mortuária deve, em alguma medida, se aproximar do gesto do torturador. Ou, na medida em que o resultado desse gesto remete a uma realidade inequívoca, do fotógrafo. Somente a partir deste ponto de vista podemos pensar nesses objetos de arte como documentos de seu tempo.

Em "X", a arte eleva-se em um alto status de autonomia, ao mesmo tempo em que servindo de exílio, altamente vincula-se a seu tempo. A negação explícita, textual, da realidade política, por si é um manifesto contra aquilo de que não se fala. A arte que nega o realismo nega o real e a realidade, ao mesmo tempo em que muito nos diz sobre ela. Declara-nos os interditos no desarmônico, nas secções das palavras, na deformação ou negação do verso, no descompasso do ritmo, na precariedade da estrofe. A estrofe oval em "X", rica em sobredeterminação, em intertextos, em significados, com palavras e versos condensados como numa granada, que ao olharmos imediatamente a que lhe procede, soa-nos, visual e auditivamente, como uma explosão que vai até os limites da

\footnotetext{
35 "Cair" era a forma como os militantes contrários à ditadura se referiam aos que eram presos ou mortos pelo regime.

${ }^{36}$ A pergunta é em italiano para demarcar o intertexto com o livro de Primo Levi: Se questo è un uomo? (É isto um homem?)
} 
página. Eis a década de 70, seus homens e seus corpos. Eis o que a poesia de Max, em sua negação, registra.

Max Martins, a exemplo de Carlos de Oliveira, Luiza Neto Jorge, Ruy Belo e Herberto Helder, poetas que escreveram durante a ditadura salazarista em Portugal, busca apresentar respostas para determinadas questões (estéticas, sociais, sociais por causa das estéticas, estéticas por causa das sociais). "X"! O gesto poético de escavacar a linguagem e de gritar-se numa busca de "te-em-mim" dentro de um lago, como lemos em "Koan", muito esclarece sobre este eu-lírico que se transmuta de um poema a outro. Preso/(auto)exilado numa linguagem em que o eu-lírico constrói destruindo e em que se constrói destruindo-se de modo autofágico e regurgitativo, na ambiguidade autoprofanação/auto-erotização. À/A "hora do juízo": afinal, qual a pergunta e a busca contida no poema "X”? No segundo poema da série "Travessia" (também publicado em H'era), lemos: "palavras famintas pediam bis, e o X / de Hamlet e Henry Miller se visava". Sô/So! ${ }^{37}$ What's the question? "To be or not be, poem?" "Be!" The poem is the question, is the ask, is the end. Linguagem!

\section{REFERÊECIAS:}

ADORNO, T. W. "Late Style in Beethoven", 1937. In: Moments musicaux. Frankfurt, Surkamp, 1964.

ADORNO, T. W. "O ensaio como forma". In: Notas de Literatura I. Tradução de Jorge de Almeida. São Paulo: Duas Cidades/ Editora 34, 2003.

BENJAMIN, W. "O narrador. Considerações sobre a obra de Nikolai Leskov". In: Obras escolhidas, vol. 1, Magia e técnica, arte e política. Tradução de Sérgio Paulo Roaunet. São Paulo: Brasiliense, 1994.

FOUCAULT, M. O que é um autor? Tradução de Antonio Fernando Cascais e Edmundo Cordeiro. Lisboa: Veja, 2000.

MARTINS, M. Poemas reunidos: 1952-2001. Belém: EDUFPA, 2001.

NUNES, B. "Max Martins, mestre-aprendiz" (prefácio, 1991). In: MARTINS, Max. Poemas reunidos: 1951-2001. Belém: EDUFPA, 2001.

${ }^{37}$ Sô! É uma expressão caipira/cabocla, tanto interjeição de espanto quanto redução de 'senhor'. 
SAID, E. W. Estilo tardio. Tradução de Samuel Titan Jr. São Paulo: Companhia das Letras, 2009.

SERRA, P. O seu a seu tempo: Luiza Neto Jorge e a questão do estilo tardio. 2013 (Seminário). 